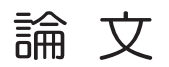

Original Paper

\title{
Reaction Mechanism in Copper-making Stage of PS Copper Converter
}

by Harumasa KUROKAWA ${ }^{\mathrm{a}}$ and Nobumasa KEMORI ${ }^{\mathrm{b}}$

a. Sumitomo Metal Mining Co., LTD., Copper \& Precious Metals Business Unit, 3-5-3, Nishihara-cho, Niihama, Ehime 792-8555, Japan (Corresponding author : E-mail Harumasa_Kurokawa@ni.smm.co.jp)

b. Sumitomo Metal Mining Co., LTD., Nickel Metal Business Unit

Oxygen probes were applied to a PS converter in copper-making operation, and the oxygen pressures of white metal and blister copper in the converter were measured through the converter's mouth and through a tuyere, respectively. Based on the obtained results, the following reaction mechanism has been deduced.

(1) The copper-making stage of a PS converter may be classified into three stages, i.e. the early substage where the tuyeres are completely in white metal, the intermediate substage where both phases of white metal and blister copper coexist in the converter and the tuyeres are in the blister copper, and the final substage where the white metal has disappeared from the converter.

(2) In the early stage, direct oxidation of white metal by oxygen gas contained in the reaction air progresses in the vicinity of the tuyeres.

$\mathrm{Cu}_{2} \mathrm{~S}(l)+\mathrm{O}_{2}(g)=2 \mathrm{Cu}(l)+\mathrm{SO}_{2}(g)$

(3) In the intermediate substage, the following three reactions proceed near the tuyeres, at the interface of blister copper and white metal phases, and in the bulk of the blister copper, respectively.

\begin{tabular}{|c|c|}
\hline $\mathrm{O}_{2}(g)$ & $=2 \underline{\mathrm{O}}(l)$ \\
\hline $\mathrm{Cu}_{2} \mathrm{~S}(l)$ & $=2 \mathrm{Cu}(l)+\underline{\mathrm{S}}(l)$ \\
\hline
\end{tabular}

$\underline{\mathrm{S}}(l)+2 \underline{\mathrm{O}}(l) \quad=\mathrm{SO}_{2}(g)$

Here the most important factor is that reaction(4) progresses under the condition of $P_{\mathrm{SO}_{2}} \fallingdotseq 1$ atm. It is not dependent on how high the $\mathrm{SO}_{2}$ pressure of the waste gas from the converter is. Because the condense phases, i.e. the white metal and blister copper phases, are not in equilibrium with the gas phase.

(4) In the final substage, reactions(2) and (4) only proceed because the white metal is no longer in the converter. Some of the blister copper can be excessively oxidized to the extent that $\mathrm{Cu}_{2} \mathrm{O}(s)$ is formed according to equation(5). However the final degree of oxidation of the whole blister copper does not reach this level.

$$
2 \mathrm{Cu}(l)+\frac{1}{2} \mathrm{O}_{2}(g)=\mathrm{Cu}_{2} \mathrm{O}(s)
$$

KEY WORDS : PS Converter, Copper-making, Oxygen Pressure, Reaction Mechanism

1. 緒

言

自溶製錬技術の進歩により，銅精鉱中の銅品位が高い，あるい は鉄品位が低いといった制限条件が付くものの，転炉を持たない 二三の銅製錬所 ${ }^{1)}$ が稼働を開始してから久しい。また，近年におけ る $\mathrm{SO}_{2}$ ガス放出に伴う環境問題への対応や, 生産性および投資採 算性の向上を目的として，フラッシュ転炉を採用する銅製錬所 ${ }^{2)}$ も出現した。しかしながら, 従来から転炉の排ガスを硫酸製造工 程で処理し, $99.9 \%$ 以上の固定率を誇る国内製錬所はもとより，世 界の銅製鍊所におけるPeirce Smith(PS)転炉の重要性は今も変わら ない。これは, PS 転炉自身は今から約 100 年前に開発された古い 炬であるが，操作性が非常に良いばかりでなく，多くの欠点が生

* 2002 年 9 月 18 日受付 2003 年 1 月 22 日受理

1. 普通会員 住友金属鉱山 (株) 金属事業本部 銅・貴金属事業部 東予工場副 工場長

2. 普通会員 工博 住友金属鉱山(株) 金属事業本部 ニッケル事業部 事業部 長兼ニッケル工場長

[ 著者連絡先 ] E-mail : Harumasa_Kurokawa@ni.smm.co.jp (住友金属鉱山・黒川) キーワード：PS 転炉，造銅反応，酸素分圧，反応機構
産に従事する技術者によって改善されてきたからである。その結 果, Outokumpu 型自溶炉と PS 転炉の組み合わせは, 今でも乾式 銅製鍊プロセスの主流となっている。

PS 転炉が 20 世紀初頭に銅製錬に導入され，すでに 100 年近く が経過したとはいえ，PS 転炉内の速度論的現象に関しては，ま だ十分に解明されていない点が多くある。そのため, Brimacombe

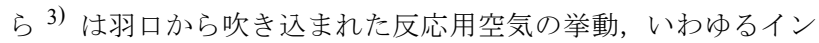
ジェクション現象に着目し, ガスの排出, 炉内各相の混合, 溶体 の飛散, ガス・液・固相間の反応速度等について, 一連の研究を 報告した。

筆者らは，このように高度に複雑化した現象のみならず，PS 転 炉内の製鍊反応そのものについても，いくつか不明な点があると 考えている。例えば，「非鉄金属製錬」4)においては，転炉の造銅 反応を溶融白鈹から粗銅一の空気による直接転化反応 $\left(\mathrm{Cu}_{2} \mathrm{~S}(l)+\right.$ $\left.\mathrm{O}_{2}(g)=2 \mathrm{Cu}(l)+\mathrm{SO}_{2}(g)\right)$ と考え, 従来の考え方の一つである酸化第 一銅の生成の可能性を否定し, また造銅反応の進行については $\mathrm{Cu}$ $\mathrm{Cu}_{2} \mathrm{~S}$ 系状態図の上でおよそ説明できると述べている。しかし PS 転炉の造銅期においては，反応用空気は羽口を介して常に白鈹の 
中に吹き込まれているわけではなく，吹錬の進行とともに，炉内 に生成した粗銅に吹き込まれることになる。このような吹錬状態 の変化にかかわらず，造銅反応が前述の形でのみ進行するとは考 え難い。そこで本研究ではPS 転炉の造銅期において炉内に存在す る白鈹および粗銅の酸素分圧 ${ }^{\text {a) }}$ を吹鍊の進行とともに測定し，造 銅反応の理解を深めることにした。

\section{2. 測定}

\section{$2 \cdot 1$ 測定原理}

本研究においては，次に示す酸素プローブ [I] を使用した。

$\mathrm{Fe}, \mathrm{FeO} / \mathrm{ZrO}_{2}(+9 \mathrm{~mol} \% \mathrm{MgO}) / \underline{\mathrm{O}}$ in White metal

or Blister copper

測定極および参照極の酸素分圧はジルコニアの電解質領域 ${ }^{5)}$ に 入っているので, 酸素プローブ $[\mathrm{I}]$ の起電力 $E(\mathrm{mV})$ は式 (1) で与 えられる。

$E=\frac{R T}{4 F} \ln \frac{P_{\mathrm{O}_{2}}^{\prime \prime}}{P_{\mathrm{O}_{2}}^{\prime}}$

$P_{\mathrm{O}_{2}}^{\prime}$ : 参照電極 $\mathrm{Fe}, \mathrm{FeO}$ の平衡酸素分圧 $(\mathrm{atm})$ $\left.\left(R T \ln P_{\mathrm{O}_{2}}^{\prime}=-526,800+129.6 T, \mathrm{Jmol}^{-1}\right)^{6}\right)$

$P_{\mathrm{O}_{2}}$ : : 溶体中の酸素分圧 $(\mathrm{atm})$

$F \quad$ : ファラデー定数 $\left(96.485 \mathrm{JmV}^{-1} \mathrm{~mol}^{-1}\right)$

$R$ : 気体定数 $\left(8.3144 \mathrm{Jmol}^{-1} \mathrm{~K}^{-1}\right)$

$T$ : 絶対温度 $(\mathrm{K})$

したがって一方の電極の酸素分圧が既知であれば, 酸素プローブ [ I ] の起電力と温度を測定することによって, 他方の電極の酸素 分圧を求めることができる。

\section{$2 \cdot 2$ 酸素分圧の標準化}

酸素分圧を用いて溶体の酸化度を判定する場合, 使用する酸素 分圧はすべて同一温度で評価されたものでなくてはならない。し かしながら, 操業している転炉の溶体温度は常に変化しており,

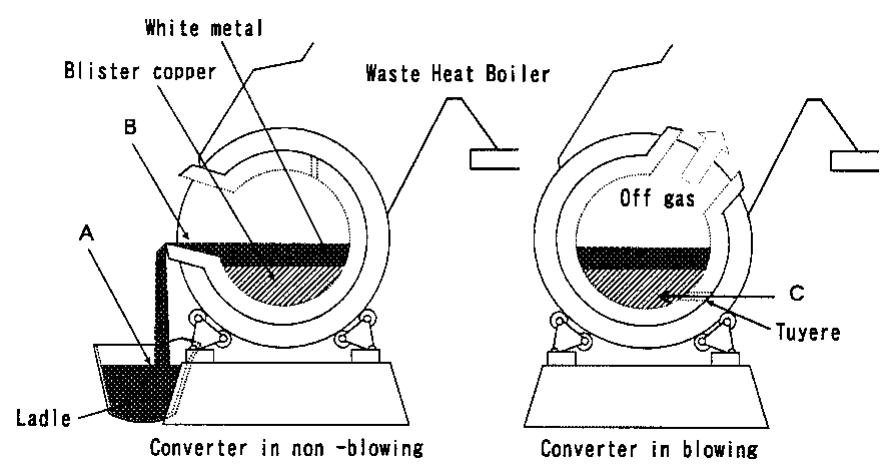

Fig.1 Location of oxygen pressure measurements in a PS copper converter. $\mathrm{A}$ : in a ladle, $\mathrm{B}:$ at the converter mouth, $\mathrm{C}$ : through a tuyere
同じ温度での酸素分圧測定は不可能である。そこで, 測定された 酸素分圧をある一定温度に標準化させる必要がある。筆者ら 7) は, 温度が少し变化しても白鈹および粗銅中に溶解している酸素濃度 が変化しないと仮定して, 下記の式により標準化を行い, その妥 当性を確認しているので, 本研究でも採用した。

(1) 白鈹

$\log P_{\mathrm{O}_{2}}^{*}=\log P_{\mathrm{O}_{2}}+\frac{39,200 \log e^{\mathrm{b})}\left(T^{*}-T^{\prime \prime}\right)}{T^{\prime \prime} T^{*}}$

$P_{\mathrm{O}_{2}}^{\prime}, P_{\mathrm{O}_{2}}^{*}$ : 測定酸素分圧および標準化酸素分圧

$T^{”,}, T^{*} \quad$ : 測定温度および標準化温度

(2) 粗銅

$\log P_{\mathrm{O}_{2}}^{*}=\log P_{\mathrm{O}_{2}}+\frac{\log e\left(19,980+6,880 N_{0}\right)\left(T^{*}-T^{\prime \prime}\right)}{T^{\prime \prime} T^{*}}$

$N_{0}:$ 酸素のモル分率

\section{$2 \cdot 3$ 測定方法}

転炉内の溶体に関して, その酸素分圧を測定する方法としては, Fig. 1 に示すように 3 種類が考えられる。すなわち, 転炬内の溶体 をいったんレードルに排出して測定する方法 (A), 転炉を停風位 置に保持して炉口から測定する方法 (B), そして吹鍊中に羽口を介 して測定する方法 $(\mathrm{C})$ である。レードルでの測定は安定した酸素 プローブの起電力が得られることが期待できる反面, 吹錬の経過 に伴う酸素分圧の変化を調べるには, 操業に多大な負担を強いる ために適当ではない。炉口からの測定は操業への負担も比較的少 なく, 白鈹中酸素分圧の経時変化を調べるのに適しているが，前 報 7) で明らかになっているように測定そのものが失敗に終わる可 能性がある。羽口からの測定はまさに「その場測定」であり, 造 銅期全般, 特に終点間際の酸素分圧の急激な变化を調べるには不 可欠な方法であるが，吹鍊の初期を除いて羽口近傍は粗銅で満た されていることに注意を払う必要がある。

Fig.2 は羽口からの酸素分圧測定を模式的に示したものである。 吹錬中は羽口鋼球が反応用空気の圧力により炉外側に押し つけられており, 羽口の溶体側にマッシュルームが生成して 羽口が閉塞してくると, 炉外側より羽口内にパンチングロッ ドを挿入してマッシュルームを除去する。このとき, 鋼球は 羽ロボックス内上部に押しつけられる。本研究の測定におい ても, 吹鍊中に図に示す羽ロボックスの内径にほぼ等しい外 径を有する治具 ${ }^{8)}$ を差し込んで鋼球を上部に押しつけ，こ の治具内に酸素プローブを挿入し, 酸素プローブの先端が炉 内の溶体に約 $100 \mathrm{~mm}$ 浸漬するようにした。

a) 本研究では, 1atmにおける純粋な酸素ガスを標準状態にした場合の 酸素の活量の 2 乗を溶体の酸素分圧と呼ぶ。

b) 自然対数の底

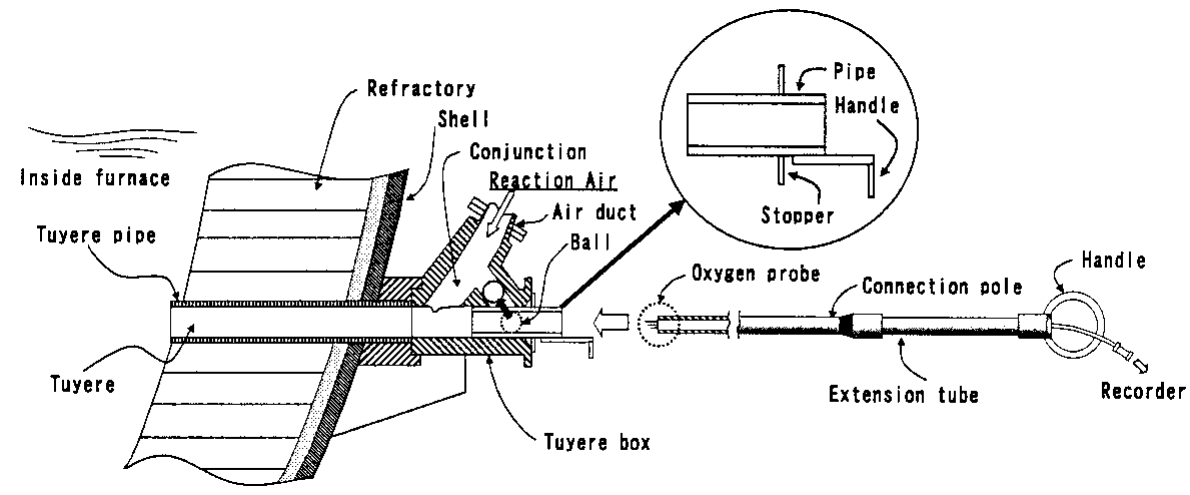

Fig.2 Schematic diagram of oxygen pressure measurements through a tuyere. 
Table 1 Cycle of two converters operation.

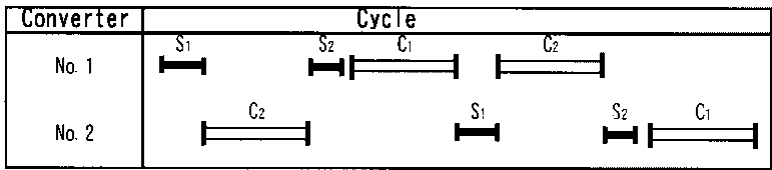

$\mathrm{S}_{1, \mathrm{~S}_{2}}$ : the first and second stages of slag making blow $\mathrm{C}_{1}, \mathrm{C}_{2}$ : the first and second stages of copper-making blow.

\section{$2 \cdot 4$ 測定時期}

標準的な転炉操業においては，3 基の転炉を保有し，2 基を稼動 させて交互に吹鍊し, 残る 1 基で棟瓦補修を実施する。稼動して いる 2 基の転炉操業については，吹錬時間率を高めて生産性を上 げるため, 各社いろいろ工夫しているが，本研究を実施した東予 製錬所における転炉操業サイクルを Table 1 に示す。造鍰期と造 銅期をそれぞれ 2 期に分割し，転炉 2 基の吹鍊スケジュールに特 徵があるが，詳しい説明は別報 ${ }^{9)}$ に譲る。本研究では，造鍰 II 期 (S2) が終了した時点で白鈹の酸素分圧を測定し，造銅期開始時の 酸素分圧とした。造銅期はそれぞれ約 120 分間の I 期 (C1) と II 期 (C2) に分割されているが，この分割や吹錬中に投入される冷材は 炉内溶体の酸化度に影響を及ぼさないものとして, 測定データを 処理することにした。造銅期終了後は，炉内の粗銅をレードルに 排出して酸素分圧を測定し, 造銅期における最終の酸素分圧とし た。

\section{3. 結果}

\section{$3 \cdot 1$ 起電力波形}

造銅 I 期終了後の白鈹についての酸素プローブの起電力波形を Fig.3に示す。(a) はレードルでの, また (b) は炉口での測定結果で ある。レードルでの測定においては, 非常にきれいな波形が得ら
れており, 本研究で使用した酸素プローブの特徵である参照電極 $\mathrm{Fe} \cdot \mathrm{FeO}$ に起因した初期ピーク 5) がはっきりと認められる。初期 ピークの後, 起電力はいったん下がるがすぐに上昇し, 安定した 值が得られている。一方, 炉口での測定においては, レードルほ どきれいで滑らかな波形は得られていないが, 測定開始から 10 秒 経過した以降は, わずかなハンチングがあるものの安定しており, 炉口での測定も十分可能であることがわかった。前報 7)では炉口 での測定は不可能と結論づけたが，失敗の原因は炉口から溶体を 流れ出させながら測定したため, 酸素プローブの先端が流体に よって破損したからであった。本研究では白鈹を流出させること なく炉口付近に保持し, その中に酸素プローブを浸漬して測定中 は酸素プローブの先端を細かく振動させた。酸素プローブの先端 を振動させる目的は, 平衡起電力值が短時間に得られるようにす るためであり, ジルコニア内外の温度差に起因した熱起電力, ジ ルコニアの安定化剤 $\mathrm{MgO}$ の溶解による拡散電位を小さくするため にも有効である。なお，造鍰 II 期終了後の白鈹についても， Fig.3 (a)，(b) と同様な波形が得られた。

Fig.4 は羽口を介しての起電力波形を示したものであり, 波形 (a) は造銅期の初期 (吹錬時間 30 分以内), 波形 (b) は中期 (吹錬 開始 30 分後から吹錬終了 30 分前までの約 180 分間), そして波形 (c) は後期（吹錬終了までの 30 分間 ) の代表的な結果である。(a) の測定は，造銅期の吹錬開始直後に実施されており，羽口近傍の 溶体は白鈹である。ハンチングが少なく, 比較的安定した起電力 が得られている。造銅期の中期においては, 羽口近傍の溶体はす でに白鈹から粗銅に変わっているが，(a)または (b) の波形が得ら れた。波形 (b) の特徴は, (a) に比べてハンチングの頻度が多いこ とであり，ハンチング幅はあまり変わらないか少し大きい。中期 における波形 (a) と (b) の出現頻度はほぼ同じであるが, 中期の終

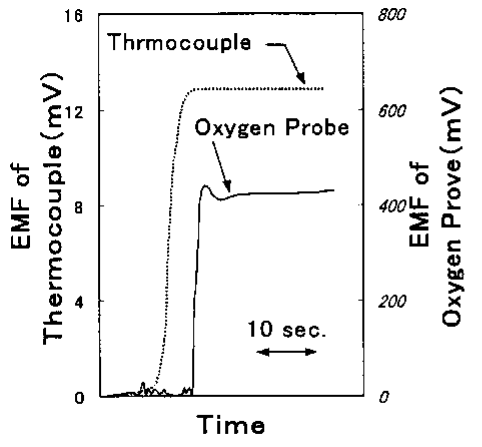

(a)

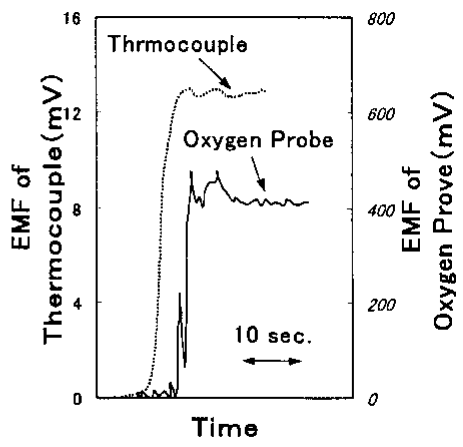

(b)

Fig.3 Recorder traces for white metal.

(a). measured in a ladle. (b). measured at the converter mouth.

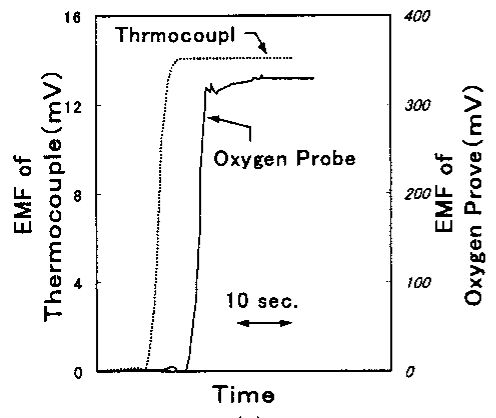

(a)

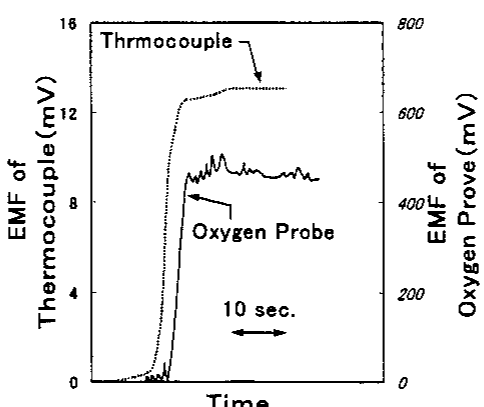

(b)

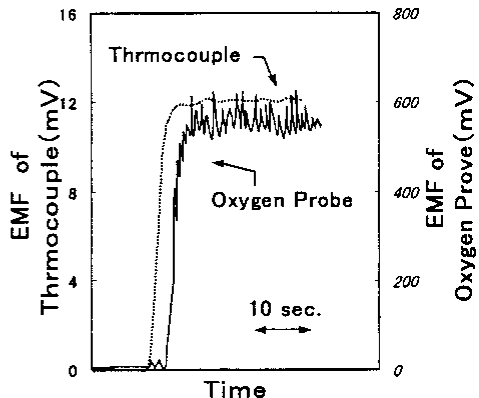

(c)

Fig.4 Recorder traces measured through a tuyere.

(a). for white metal in an early stage of copper-making blow $\left(\mathrm{C}_{1}\right)$

(b). for blister copper in a middle stage of copper-making blow $\left(\mathrm{C}_{1}\right.$ and $\left.\mathrm{C}_{2}\right)$.

(c). for blister copper in a final stage of copper-making blow $\left(C_{2}\right)$. 
Table 2 Comparison of oxygen pressures for white metal measured at the converter mouth and in a ladle.

\begin{tabular}{|c|c|c|c|c|c|c|c|}
\hline Timing & Locatoin & Run & $\mathrm{E} / \mathrm{mV}$ & Temp. $/{ }^{\circ} \mathrm{C}$ & $\log$ & $\left(\mathrm{PO}_{02}^{*} / \mathrm{atm}\right)$ & at $1200^{\circ} \mathrm{C}$ \\
\hline \multirow{5}{*}{ After $\mathrm{S}_{2}$} & Mouth & 1 & 273.2 & 1318 & & -7.92 & \\
\hline & & 2 & 288.6 & 1312 & & -7.74 & \\
\hline & Ladle & 1 & 286.2 & 1295 & & -7.80 & \\
\hline & & 2 & 313.4 & 1261 & & -7.51 & \\
\hline & & 3 & 273.2 & 1232 & & -8.10 & \\
\hline \multirow[t]{4}{*}{ After $\mathrm{C}_{1}$} & Mouth & 1 & 429.5 & 1219 & & -6.02 & \\
\hline & & 2 & 422.1 & 1221 & & -6.12 & \\
\hline & Ladle & 1 & 433.6 & 1193 & & -5.98 & \\
\hline & & 2 & 429. 5 & 1190 & & -6.04 & \\
\hline
\end{tabular}

Table 3 Reproducibility of oxygen pressures for blister copper measured in ladles.

\begin{tabular}{cccccc}
\hline Ladle & Run & $\mathrm{E} / \mathrm{mV}$ & Temp. $/{ }^{\circ} \mathrm{C}$ & $\log \left(\mathrm{Po}^{*} / \mathrm{atm}\right)$ & at $1200^{\circ} \mathrm{C}$ \\
\hline 1st & 1 & 520.0 & 1167 & -4.91 \\
& 2 & 522.1 & 1169 & -4.87 \\
4th & 1 & 526.7 & 1162 & -4.83 \\
& 2 & 525.5 & 1164 & -4.84 \\
\hline
\end{tabular}

わりには波形 (b) が多く現れる。波形 (b) においては，ハンチング の底の值を測定值として採用した。終期においては, 波形 (c) のみ が得られた。その特徵は，ハンチングの頻度と幅にあり，波形 (b) と比較してもその違いは明らかである。波形 (c) の測定值として は，ハンチングの中央值を採用することにした。

\section{$3 \cdot 2$ 炉口での測定精度}

$3 \cdot 1$ の結果から明らかなように, 白鈹の酸素分圧は炉口よりも レードルの方が精度良く測定できる。しかしながら，吹鍊の経過 と共に白鈹がどのように酸化されていくかを調べるには，炉口で の測定の方がはるかに簡便である。また，レードルでの測定にお いては，炉内の白鈹をいったん排出する過程で白鈹の酸化が進む 懸念があり，この点においても炉口での測定の方が優れていると 考えられる。そこで造鍰 II 期後および造銅 I 期後の白鈹を対象と して, 炉口ならびにレードルでの測定精度を調べることにした。

測定結果を Table 2 に示す。造銅 I 期終了後の白鈹については, 各測定場所での再現性は良好であり, 炉口とレードルとの差も認 められなかった。造鍰 II 期終了後の白鈹についても, 炉口での再 現性に問題はなく, レードルにおける測定結果とも平均值におい ては一致していた。レードルでの 3 個の測定結果が比較的大きな ばらつきを示しているのは, 造鍰 II 期終了後の白鈹には若干の FeS がまだ残っており，この $\mathrm{FeS}$ の多塞が白鈹の酸素分圧に大きな影 響 10)を与えるためと考えられる。つまり，炉内白鈹をレードルへ 排出する過程で残留 $\mathrm{FeS}$ の一部が酸化除去される可能性があるが, この除去度合いがそのときの排出状況によって影響を受けると推 察されるからである。一方, 造銅 I 期終了後の白鈹は粗銅と共存 しており，酸素に対する緩衝能力が高いため, 測定場所にかかわ らず再現性が良いものと考えられる。

\section{$3 \cdot 3$ 再現性}

造銅 II 期終了後の粗銅の酸素分圧は, 造銅期の終点を示寸值と して非常に重要であるため, 測定精度が最も高いと考えられる レードル中で測定することにした。通常操業においては，1 回の 転炉操業で約 $190 \mathrm{t}$ の粗銅が生成し，これらすべてを 4 〜 杯の レードルに受けて精製炉に移送する。転炉内に生成した粗銅のど こを取っても同一の酸化度を有しているかどうかを調べるため, 最初と最後 (すなわち, 1 杯目と 4 杯目) のレードルで酸素分圧を 測定し，比較することにした。また，データの再現性も合わせて 調查するため, 各 2 回の測定を実施した。

すべての測定結果を Table 3 に示す。各レードルでの再現性は

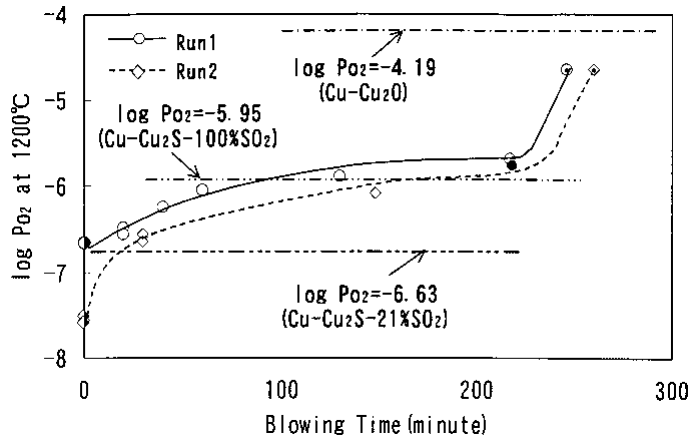

Fig.5 Variation of oxygen pressures during copper-making blow. $\odot, \diamond, \diamond, \diamond:$ for white metal at the converter mouth.
: for blister copper through a tuyere during blowing.
: for blister copper in a ladle after blowing.

非常に良く，またレードル間にも有意差は認められなかった。し たがって, 転炉で生成した粗銅は均一に酸化されており, その酸 素分圧は 1 杯目のレードルで測定できることがわかった。

\section{$3 \cdot 4$ 造銅期酸素分圧の経時変化}

$3 \cdot 4 \cdot 1$ 炉内白鈹造鍰期終了後の白鈹に対して酸素分 圧の測定を炉口で実施し，造銅 I 期開始時の白鈹の酸素分圧とし

て Fig.5 に記号しくで示した。また，造銅期終了時の生成粗銅 をレードルにすべて排出し，1杯目のレードルでの測定值を終点

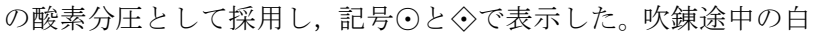
鈹の酸素分圧は, 所定時間が経過した時点でその都度羽口からの 送風を停止し，転炉を傾転させて炉口から短時間の内に測定した ( 記号○, ๖)。Run1 と 2 の 2 回測定を行ったが, Run1において は終点 30 分前に羽口を介して炉内粗銅の酸素分圧を測定し, 記号 ○で図中に一緒に示した。

Fig.5 より, 転炉の造銅期においては, 炉内溶体は 3 段階で酸化 されて粗銅に転化されることがわかる。すなわち, 酸素分圧がほ ぼ一定に保たれる中期と, その前後の初期および後期の 3 段階で ある。初期における酸素分圧の上昇度は，造銅期開始，つまり造 鍰期終了後の白鈹の酸素分圧に依存する。Run2 のように開始時の 酸素分圧が低い場合は，吹鍊の開始に伴って酸素分圧が急激に上 昇するが，Run1のような場合には比較的緩やかな上昇を示す。造 鍰期終了時の白鈹の酸素分圧がこのように大きく変動する理由 は, 矢沢 ${ }^{10)}$ による $\mathrm{Cu}-\mathrm{S}-\mathrm{O}$ 系のポテンシャル図に示されているよ うに, 白鈹中の銅品位, つまり鉄品位によって系の酸素分圧が大 きく変化するという治金学的理由と, 造鍰期の終点判定が難しい という操業的理由による。初期と中期の境界を明確に決めること は難しいが，Fig.5 からは 100 分程度と見な寸ことができるかもし れない。なお，吹錬状態において羽ロレベル以下の炉内溶体がす べて粗銅に転化するにはおよそ 90 分を要し, 前述の時間とほぼ一 致する。終期の酸素分圧変化が最も大きいが，この領域において は測定点がわずか 2 点しかないので, 測定データの多い次項にお いて述べる。

$3 \cdot 4 \cdot 2$ 羽口粗銅造銅終期の炉内溶体の酸素分圧変化を 述べるため, 造銅 II 期全般にわたって羽口を介して測定を行った。 終点 30 分前からは測定頻度を上げ, $3 \cdot 4 \cdot 1$ の結果から予想され る急激な酸素分圧の上昇を正確に捉えることができるようにし た。結果をFig.6に示すが，予想通り羽口近傍の粗銅は終点 30 分 前から上昇を開始し，吹錬時間に対して直線的に上昇し，最終的 にはレードルで測定された值に至ることがわかった。また，炉内 白鈹と同様に, 羽口近傍の粗銅についても造銅中期においては酸 素分圧がほぼ一定值を示すことがわかった。 


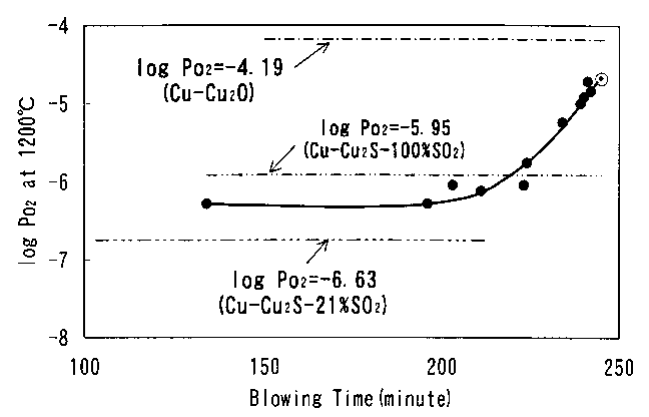

Fig.6 Variation of oxygen pressures during copper-making blow. - : for blister copper through a tuyere during blowing. $\odot$ : for blister copper in a ladle after blowing.

\section{4. 考察}

\section{$4 \cdot 1$ 白鈹と粗銅の酸化度上限}

白鈹と粗銅の酸素分圧の上限はそれぞれ反応式 [ II ], [ III] によっ て規定され，その值は式 (4)，(6)によって与えられる。

$\mathrm{Cu}_{2} \mathrm{~S}(l)+\mathrm{O}_{2}(g)=2 \mathrm{Cu}(l)+\mathrm{SO}_{2}$

$\log P_{\mathrm{O}_{2}}=\Delta G^{\circ}[$ II $] \log e / R T+\log P_{\mathrm{SO}_{2}}$

$\Delta G^{\mathrm{O}}[\mathrm{II}] / \mathrm{Jmol}^{-1}=-221,070+36.15 T^{11)}$

$2 \mathrm{Cu}(l)+\frac{1}{2} \mathrm{O}_{2}(g)=\mathrm{Cu}_{2} \mathrm{O}(s)$

$\log P_{\mathrm{O}_{2}}=2 \Delta G^{\circ}[\mathrm{III}] \log e / R T$

$\Delta G^{\circ}[\mathrm{III}] / \mathrm{Jmol}^{-1}=-400,000+191.36 T^{12)}$

銅の酸素分圧の上限值は温度のみを指定すれば一意的に定まる が，白鈹のそれは温度の他に $\mathrm{SO}_{2}$ 分圧も指定する必要がある。本 研究を実施した転炉の造銅期においては酸素富化を行っていない ため, 気相中の $\mathrm{SO}_{2}$ 濃度は $21 \%$ と寸ることができる。ただし, 白 鈹が存在し得る最大の酸素分圧は $\mathrm{SO}_{2}$ 濃度 $100 \%$ に対応する。

$1,200{ }^{\circ} \mathrm{C}$ において粗銅が存在し得る最大の酸素分圧および白鈹 のそれ (ただし, $\mathrm{SO}_{2}$ 濃度 $100 \%$ および $21 \%$ における值 )をそれ ぞれ一点, 二点, 三点鎖線として Fig. 5 ， 6 亿示す。造銅期終点に おけるレードル中で測定された粗銅の酸素分圧は, 式 (6) で与え られる最大值を超えておらず矛盾がない。しかし, 前報 ${ }^{7)}$ で報告 したように, 終点近くで羽口から測定された酸素プローブの起電 力值はハンチング幅が大きく，そのピークに対応した酸素分圧は $\mathrm{Cu}_{2} \mathrm{O}(s)$ の安定領域に入っていた。本研究でも Fig.4(c) に示された ハンチングのピーク起電力值は前述の最大值を超えており, 同様 の現象が確認できた。一方，白鈹については，Fig.5に示すように 本研究で得られた標準化酸素分圧の多くは, $\mathrm{SO}_{2}$ 濃度 $21 \%$ に対応 した式 (4) の值よりも高かった。転炉吹錬に使用した反応用空気 中の酸素濃度は $21 \%$ であり, 排ガス中の $\mathrm{SO}_{2}$ 濃度が $21 \%$ を超え ることはなく, Fig.5 の結果は PS 転炉の構造を考慮して初めて合 理的な理解が可能になる。つまり，造銅中期においては羽口近傍 の溶体はすでに粗銅に転化しており, 粗銅中の酸素分圧は最大 $10^{-}$ $4.19 \mathrm{~atm}$ まで上昇できる。しかし，転炉内には白鈹が存在しており， 粗銅に対して硫黄を供給し続け, 粗銅の酸素分圧を低下させよう とする。つまり, 転炉内の溶体の酸素分圧は, 反応用空気による 酸化力と白鈹による還元力のバランスによって決定されている が, 炉内溶体の攪拌力に乏しい PS 転炉では還元力が酸化力に劣る 結果, 炉内溶体が示寸酸素分圧に対応した $\mathrm{SO}_{2}$ 濃度が $21 \%$ を超 え，場合によっては $100 \%$ に至ることとなる。したがって，PS 転 炉においては, 炉内の凝縮相 ( 白鈹と粗銅) はガス相と平衡状態 にないと考えられる。ただし, Fig.5 の Run1 の結果より, 白鈹と 粗銅は平衡しているものと思われる。

Fig.5 に示された白鈹の標準化酸素分圧には, もう一点奇妙な
Table $4 \quad P_{\mathrm{SO}_{2}}$ calculated by $P_{\mathrm{O}_{2}}$ data and equation (4).

\begin{tabular}{cccc}
\hline E/mV & Temp. $/{ }^{\circ} \mathrm{C}$ & $\log \left(\mathrm{Po}_{2} / \mathrm{a}\right.$ tm) & $\mathrm{Pso}_{2} / \mathrm{atm}$ \\
\hline 396.3 & 1203 & -6.46 & 0.30 \\
391.7 & 1203 & -6.52 & 0.26 \\
414.0 & 1210 & -6.16 & 0.55 \\
429.7 & 1187 & -6.14 & 0.76 \\
444.3 & 1158 & -6.20 & 0.96 \\
459.7 & 1097 & -6.55 & 0.98 \\
\hline
\end{tabular}

ところがある。それは, $\mathrm{SO}_{2}$ 濃度 $100 \%$ において存在できる白鈹 の酸素分圧よりも高い結果が得られている点である。この原因 は，造銅 I 期と II 期の操業温度に $50{ }^{\circ} \mathrm{C}$ 以上の差があるにもかか わらず, 造銅期の標準化温度として造銅 I 期の操業温度に近い $1,200{ }^{\circ} \mathrm{C}$ を選んだ結果, 造銅 II 期で得られた酸素分圧を標準化す る際に, 大幅な温度変換の操作を行うことになったからである。 すなわち, 式 (2) における $\log P_{\mathrm{O}_{2}}^{*}$ の $1 / T^{*}$ に対する係数 (負の值) の絶対值が, 式 (4) における $\log P_{\mathrm{O}_{2}}$ の $1 / T$ に対する係数の絶対值 よりも大きいため, このような結果になった。そこで, Fig.5 の Run1 の測定温度における酸素分圧に基づいて, 白鈹が示寸酸素 分圧が何 \%の $\mathrm{SO}_{2}$ 濃度に対応しているかを調べることにした。結 果を Table 4 に示すがすべて $100 \%$ 以下となっており, 矛盾がな かった。また, 予想通り, 吹鍊の進行に伴って $\mathrm{SO}_{2}$ 濃度が上昇し, 造銅中期においてはほぼ $100 \%$ の $\mathrm{SO}_{2}$ 濃度となっていることがわ かった。

\section{$4 \cdot 2$ 造銅反応}

本研究で得られた測定結果および $4 \cdot 1$ の考察より, PS 転炉に おける造銅期の総括治金反応 [ II ] は少なくとも反応式 [ II ], [IV] 〜 [VI], および [IV] と [VI ], [III] に分割できると考えられる。こ の考え方が合理的であることを, 前章の結果を参照しながら以下 に示す。

\begin{tabular}{|c|c|c|}
\hline 総括反応 & $\mathrm{Cu}_{2} \mathrm{~S}(l)+\mathrm{O}_{2}(g)$ & $=2 \mathrm{Cu}(l)+\mathrm{SO}_{2}(g)$ \\
\hline 初期 & $\mathrm{Cu}_{2} \mathrm{~S}(l)+\mathrm{O}_{2}(g)$ & $=2 \mathrm{Cu}(l)+\mathrm{SO}_{2}(g)$ \\
\hline \multirow[t]{3}{*}{ 中期 } & $\mathrm{O}_{2}(g)$ & $=2 \underline{\mathrm{O}}(l)$ \\
\hline & $\mathrm{Cu}_{2} \mathrm{~S}(l)$ & $=2 \mathrm{Cu}(l)+\underline{\mathrm{S}}(l)$ \\
\hline & $\underline{\mathrm{S}}(l)+2 \underline{\mathrm{O}}(l)$ & $=\mathrm{SO}_{2}(g) \quad \cdots$ \\
\hline \multirow[t]{2}{*}{ 後期 } & $\mathrm{O}_{2}(g)$ & $=2 \underline{\mathrm{O}}(l)$ \\
\hline & $\underline{\mathrm{S}}(l)+2 \underline{\mathrm{O}}(l)$ & $=\mathrm{SO}_{2}(g) \quad \cdot \cdot$ \\
\hline
\end{tabular}

造銅初期において羽口近傍に十分な量の白鈹が存在していると きは, 反応用空気中酸素ガスによる白鈹の粗銅への直接転化反応 [ II ] が進行する。直接転化反応が進行していることの証拠は, 転 炉内の酸素分圧が式 (4) の $\mathrm{SO}_{2}$ 濃度 $21 \%$ における值に等しいかど うかであるが, Fig.5 の Run1, 2 において吹錬開始から 15 分間程 度は両者がほぼ一致していると夕なせる。一方, 転炉の容量およ び送風空気量から求めた羽口レベル以下の白鈹をすべて粗銅に転 化するのに要する時間は約 90 分であり, 直接転化反応が進行する 時間は比較的短い。このことは, PS 転炉における炉内溶体の混合 攪挥力が極めて不十分であることを意味している。

造銅中期においては, 羽ロレベル以下の溶体はすでに粗銅に転 化しており, 粗銅相の上には白鈹相が存在している。このような 状態において, まず, 反応用空気中の酸素ガスは, 羽口近傍の粗 銅に溶解寸る ( 反応式 [IV])。炉内に共存している白鈹は, 反応式 $[V]$ に従って溶解し, 粗銅中の硫黄濃度を一定に保とうとする。粗 銅中の溶存硫黄と酸素の反応は反応式 $[\mathrm{VI}]$ に従って, 気相中の $\mathrm{SO}_{2}$ 濃度がほぼ $100 \%$ の状態で進行するが, 実際の製錬排ガス中 の $\mathrm{SO}_{2}$ 濃度は $21 \%$ であり, 白鈹および粗銅の凝縮相はガス相と平 衡していない。 
造銅終期は，転炉内の白鈹が消失したときから始まる。反応式 [V] に示される硫黄の供給源がなくなることにより，粗銅の一部 は反応式 $[\mathrm{III}]$ に従って $\mathrm{Cu}_{2} \mathrm{O}(s)$ を析出する程度まで酸化されるが, 炉内全体の粗銅の酸化度はそこまで上昇しない。

\section{5. 結言}

造銅期吹錬中の PS 転炉に酸素プローブを適用し, 炉内の白鈹お よび粗銅の酸素分圧をそれぞれ炉口および羽口を介して測定し た。得られた結果に基づいて, 次のような反応機構を導出した。

(1) PS 転炉の造銅期は羽口が白鈹に完全に浸っている初期, 炉 内に白鈹と粗銅が共存し, しかも羽口が粗銅に浸っている中期, そして炉内から白鈹が消失した終期に分けることができる。

（2）造銅初期においては，反応用空気による白鈹の直接酸化が 反応式 [ II ] に従って羽口近傍で進行する。

$\mathrm{Cu}_{2} \mathrm{~S}(l)+\mathrm{O}_{2}(g)=2 \mathrm{Cu}(l)+\mathrm{SO}_{2}(g)$

(3) 造銅中期においては, 式 [IV], [V] および [VI] に示される 3 つの反応がそれぞれ羽口近傍, 粗銅相と白鈹相の界面, そして 粗銅中で進行する。

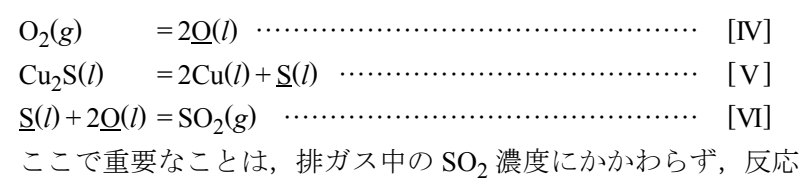

[VI] が $P_{\mathrm{SO}_{2}} \fallingdotseq 1 \mathrm{~atm}$ の条件下で進行することである。つまり，ガ
ス相は凝縮相 ( 白鈹および粗銅 $)$ と平衡していない。

（4）造銅終期においては，炉内に白鈹がないため，反応式 [IV], [VI] が進行する。粗銅の一部は反応式 [III] に従って $\mathrm{Cu}_{2} \mathrm{O}(s)$ を析 出する程度まで過剩に酸化されるが, 粗銅全体の最終酸化度はそ こまでには至らない。

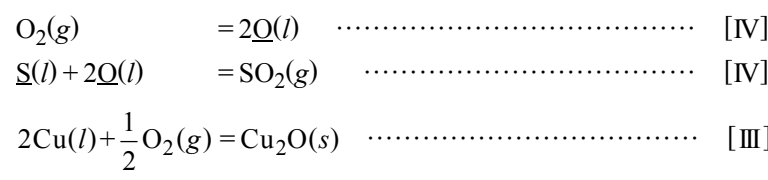

\section{References}

1) F. R. A. Jorgensen and D. N. Collins : Metallurgical Society of CIM, Copper95Cobre95, Pyrometallurgy of Copper, (1995) Vol.IV, pp.515 - 529.

2) C. J. Newman, T. I. Probert and Weddick: Sulfide Smelting ' 98 , Current and Future Practices, The Minerals, Metals \& Materials Society, (1998), pp.205-215.

3) J. K. Brimacombe, A. A. Bustos, D. Jorgensen and Richards: Metall. Trans. B, (1979), p. $327-351$.

4) A. Yazawa:Hitetsu Kinzoku Seren (Nihon Kinzoku Gakkai, Sendai, 1980), pp.80-86.

5) N. Kemori, H. Kurokawa and Z. Kouzuka:Nihon-Kogyokai, 102(1986), 41 - 47.

6) R. A. Rapp:Techniques of Metals Research, Physicochemical Measurements in Metals Research, Vol. IV, Part2,(Interscience, New York, 1970), pp.123.

7) N. Kemori, H. Kurokawa and Y. Kondoh: Shigen-to-Sozai, 108(1992), 45-50.

8) N. Kemori, Y. Kondoh, A.Watanabe and H. Kurokawa: Jitsu Kai H3-59357.

9) T. Kimura and H. Kurokawa: Proc. MMIJ Fall Meeting,(1993), T-8, pp.27-30.

10) A.Yazawa:Can. Metall. Quart., 13(1974), 443-453.

11) A. Yazawa: Hitetsu Kinzoku Seren (Nihon Kinzoku Gakkai, Sendai, 1980), pp.317.

12) N. Kemori, I. Katayama and Z. Kozuka:Trans. JIM, 21(1980), 275-284. 